\title{
An Example of Automatic Measurement \\ in the Data of Generated Power from a Photovoltaic Panel
}

\section{○坂口 鋼一 (愛知技術短大), 永田 英雄, 正 山本 照美

正 服部 幸広, 正 橋本 孝明, 西浦 幸雄（西浦電気(侏）

Koichi SAKAGUCHI, Aichi College of Technology, Nishihasama-cho, Gamagori-city, Aichi, 443-0047

Hideo NAGATA, Aichi College of Technology

Terumi YAMAMOTO, Aichi College of Technology

Yukihiro HATTORI, Aichi College of Technology

Takaaki HASHIMOTO, Aichi College of Technology

Yukio NISIURA, Nishiura Electric Corp.

Key Words: Automatic Measurement, Photovoltaic Panel

\section{1.はじめに}

雲の状況などが時々刻々変化すると、それにつれて太陽光 発電データも時々刻々変化する。このような計測には、パソ コンなどを利用した自動計測が望ましい。しかし、自動計測 が望ましく、うまく機能すれば便利であることはわかってい ても、常時かかわっている専門家にとっては非常に容易なこ とであっても、初めて自動計測を手がけようとする者にとっ ては、なかなかとっつきにくい技術であることも確かである。

筆者らも、今回、必要にせまられて太陽光発電の自動計測 システムの構築をすべき状況となった。市販の優れたソフト があり、比較的簡単に自動計測が可能ということを聞き、こ れを利用することとしたが、実際にシステムを稼動するまで にはかなりの苦労があった。そこで、太陽光発電に関しての 自動計測のシステムを組んだ経験をまとめておくこととし た。

自動計測に関しては全くの素人が、始めの一歩から行った ということで、とりあえず、太陽光パネルからの電圧をディ ジタルマルチメータに入れ、そこからパソコンに取り込み、 計測データをファイルに書き込むことを目標としたもので、 専門家からみれば極めて初歩的なシステムの構成、ソフトウ エアの利用などであろうが、入口の段階でつまずく同類の人 もあると考え、後日のために記録しておくこととしたもので ある。

\section{2. 実験装置と実験方法}

\section{1 太陽電池モジュール 1}

メーカーは昭和ソーラーエネルギー株式である。仕様はモ ジュール型式G T 172 （大型高効率高性能太陽電池モジュー ル) と呼ばれるもので、その電気出力特性はカタログによれ ば、次表 1 に示すとうりである。

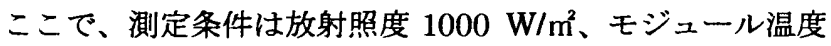
$25^{\circ} \mathrm{C}$ 、分光分布 $\mathrm{AM} 1.5$ 全天日射基準太陽光である。モジュ 一ル寸法は $\mathrm{H} \times \mathrm{W} \times \mathrm{D}=982 \mathrm{~mm} \times 869 \mathrm{~mm} \times 35 \mathrm{~mm}$ で、重量
は $11 \mathrm{~kg}$ である。

1 枚のパネルを自作の架台にとりつけ、実験を行った。

表 1 電気出力特性

\begin{tabular}{|c|c|}
\hline 最大出力 $\mathrm{Pm}$ & $109 \mathrm{~W}$ \\
\hline 最大出力動作電流 Ipm & $3.16 \mathrm{~A}$ \\
\hline 最大出力動作電圧 Vpm & $34.6 \mathrm{~V}$ \\
\hline 短絡電流 Isc & $3.47 \mathrm{~A}$ \\
\hline 開放電压 Voc & $43.2 \mathrm{~W}$ \\
\hline 適用電圧 & $24 \mathrm{~V}$ \\
\hline
\end{tabular}

\section{2。 2 予備的実験}

（1）目的 太陽電池モジュール1個によって発生した電 圧を、ディジタルマルチメータで計測し、そのデ 一タをパソコンに取り込み、市販のソフトウェア内 にあるサンプルプログラムを利用して、パソコン画 面上に表示する。

（2）使用した装置 前述の太陽光パネル以外の装置な どは 表 2 に示すとうりである。

表 2 使用した装置など

\begin{tabular}{|l|l|l|}
\hline 項目 & 装置など & メーカー \\
\hline 電圧測定 & $\begin{array}{l}\text { GPIB インターフェー } \\
\text { ス付きディジタルマ } \\
\text { ルチメータ }\end{array}$ & アドバンテスト \\
\hline コントロール & $\begin{array}{l}\text { GPIB ボード付きパソ } \\
\text { コン }\end{array}$ & デル \\
\hline ソフトウェア & $\begin{array}{l}\text { LabVIEW (OS } \\
\text { Windows) }\end{array}$ & $\begin{array}{l}\text { ナショナルインス } \\
\text { ツルンツ }\end{array}$ \\
\hline
\end{tabular}

（3）装置の接続 今回の自動計測システムでは、いくつか ある自動計測技術のうちから GPIB を利用した。今 回、構筑をめさしている太陽光発電の自動計測シス テムにおける装置の接続状況を図 1 に示す。

日本機械学会東海支部第 49 期総会講演会講演論文集 ('00. 3. 10-11) No.003-1 


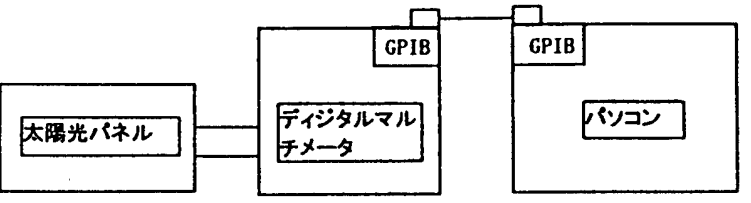

Fig. 1 Automatic Measurement System

(4) 実験経過と結果

(1)図 1 のようにシステムを組み立て、ディジタルマル チメータのファンクションとレンジを設定する。

(2)パソコンにインストールされている LabVIEW を立 ち上げ、ディジタルマルチメータの認識と計測器ドラ イバーの認識を行う。

(3)ディジタルマルチメータから送信されてくる電圧デ 一タをパソコン画面に表示するために、LabVIEWに 標準装備されているサンプルプログラム LabVIEW<->GPIB.vi を開く。

(4)LabVIEW におおるプログラム画面は、フロントパネ ルとダイヤグラムの二つの画面から構成されている が、図 2 に示す LabVIEW<->GPIB.vi のフロントパ ネルで所定の操作を行うことにより、ディジタルマル チメータに表示された太陽電池の出力を、フロントパ ネルの Characters Read に表示できることを確認す る。

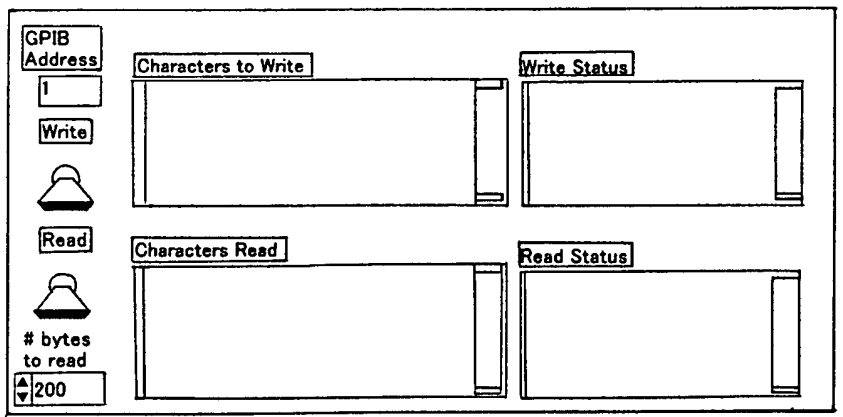

Fig. 2 Frontpanel of LabVIEW<->GPIB.vi

\section{3 実験用プログラムの作成と実験}

（1）目的「太陽電池モジュール 1 個によって発生し た電圧を、ディジタルマルチメータで計測し、その データを時間間隔を指示してパソコンに取り込み、 指定したファイルに書き込む」機能を持つプログラ ムを作成する。

（2）作成の概要

(1)サンプルプログラム LabVIEW<->GPIB.vi を所定 の操作でサブプログラム化する。

(2)サブプログラムを利用して目的のプログラムを作 成する。作成したプログラムのフロントパネルと ダイヤグラムを図 3、図 4 に示す。

（3）実験結果

太陽電池の出力電圧を、1 秒間隔で 10 回測定する 実験を行った。保存ファイルに 10 個のデータが記録 されていることは確認できた。しかし、測定時間の合 計が 10 秒とはならず、1 秒間隔で測定していないこ とがわかった。測定間隔を 5 分とした場合も同様であ った。

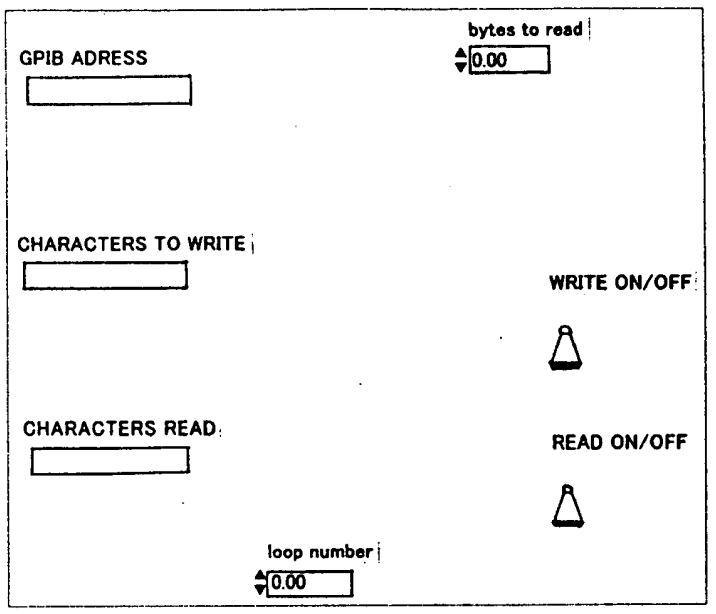

Fig. 3 Frontpanel of Program

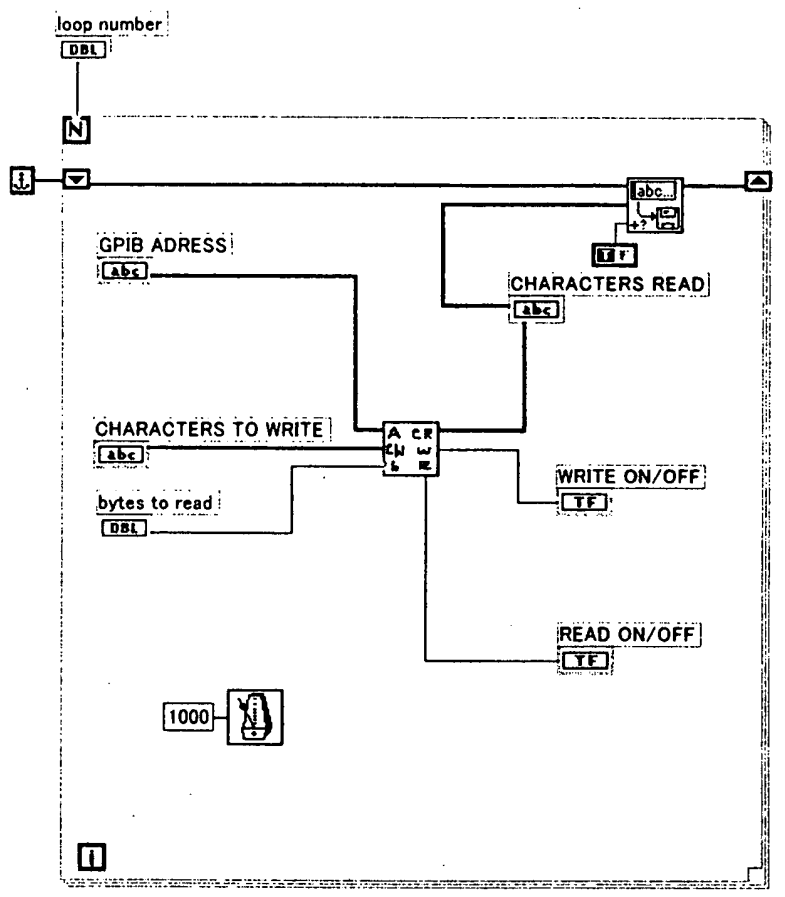

Fig. 4 Diagram of Program

\section{3 むすび}

市販のソフトウェアを利用した太陽光発電データの自動 計測の手始めに、太陽光パネルからの電圧をディジタルマ ルチメータに入れ、そこからパソコンに取り込み、計測デー タをファイルに書き込むことを目標にして行った手順をま とめたのが本報告である。設定した測定間隔で測定できず、 プログラムを一部修正する必要はあるが、今回の実験を土台 にして、今後さらに実用的な自動計測システムの構築をめざ している。

\section{4 参考文献}

1) 太陽電池モジュール取扱説明書（付属品）

製造元＼cjkstart昭和ソーラーエネルギー（株）

販売元 昭和シェル石油（株） 